\title{
Peningkatan Pemahaman Konstitusi Bagi Guru SMP Negeri 77 Jakarta
}

\author{
Iskandar Muda' ${ }^{1}$, Frengki Hardian², Sulhan³ \\ 1,2,3 Universitas YARSI Jakarta \\ email : iskandarmudaaphamk@yahoo.co.id ${ }^{1}$, frengki.hardian@yarsi.ac.id ${ }^{2}$,d.sulhan02@gmail.com ${ }^{3}$
}

\begin{abstract}
All activities at SMP Negeri 77 Jakarta located on Jl. Cempaka Putih Tengah XVII, RT. 2/RW. 8, Cempaka Putih Timur Village, Cempaka Putih District, Central Jakarta-Jakarta Province is an activity that is part of the context of the state, where in the context of the country the main reference is the constitution. Therefore, the author is responsible scientifically to improve the understanding of the 1945 Constitution as the Constitution of Indonesia for teachers in junior high school. The method used is participatory action method, namely by means of oration, dialogue and education. The results of the pre-test and post-test thoroughly without classifying the question turned out to be a significant improvement.
\end{abstract}

Keywords: improve, understanding, constitution, teacher.

\begin{abstract}
Abstrak
Segala kegiatan di SMP Negeri 77 Jakarta yang berlokasi di Jl. Cempaka Putih Tengah XVII, RT. 2/RW. 8, Kelurahan Cempaka Putih Timur, Kecamatan Cempaka Putih, Kota Jakarta Pusat-Provinsi Daerah Khusus Ibukota Jakarta adalah kegiatan yang merupakan bagian dalam konteks bernegara, dimana dalam konteks bernegara rujukan utamanya adalah konstitusi. Oleh karena itu penulis tergerak bertanggung jawab secara keilmuwan untuk meningkatkan pemahaman terhadap UUD Tahun 1945 sebagai konstitusi Indonesia bagi Guru-guru di SMP tersebut. Metode yang digunakan adalah metode participatory action, yaitu dengan cara orasi, dialog dan pendidikan. Hasil dari pre-test dan post-test secara menyeluruh tanpa mengklasifikasikan pertanyaannya ternyata terjadi peningkatan yang signifikan.
\end{abstract}

Kata Kunci: meningkatkan, pemahaman, konstitusi, guru. 


\section{Pendahuluan}

Berdasarkan Pasal 1 angka 1 Undang-Undang No. 14 Tahun 2005 tentang Guru dan Dosen (UU Guru dan Dosen) disebutkan Guru adalah pendidik profesional dengan tugas utama mendidik, mengajar, membimbing, mengarahkan, melatih, menilai, dan mengevaluasi peserta didik pada pendidikan anak usia dini jalur pendidikan formal, pendidikan dasar, dan pendidikan menengah. Selanjutnya dalam Pasal 20 UU a quo disebutkan dalam melaksanakan tugas keprofesionalan, Guru berkewajiban:

a. Merencanakan pembelajaran, melaksanakan proses pembelajaran yang bermutu, serta menilai dan mengevaluasi hasil pembelajaran;

b. Meningkatkan dan mengembangkan kualifikasi akadernik dan kompetensi secara berkelanjutan sejalan dengan perkembangan ilmu pengetahuan, teknologi, dan seni;

c. Bertindak objektif dan tidak diskriminatif atas dasar pertimbangan jenis kelamin, agama, suku, ras, dan kondisi fisik tertentu, atau latar belakang keluarga, dan status sosial ekonomi peserta didik dalam pembelajaran;

d. Menjunjung tinggi peraturan perundang-undangan, hukum, dan kode etik guru, serta nilai-nilai agama dan etika; dan

e. Memelihara dan memupuk persatuan dan kesatuan bangsa.

Mencermati kewajiban Guru pada huruf d, yaitu "menjunjung tinggi peraturan perundang-undangan..." artinya seorang Guru berkewajiban menjunjung tinggi Undang-Undang Dasar Tahun 1945 (UUD 1945). Dimana dalam sistem hukum di Indonesia, UUD Tahun 1945 sebagai konstitusi Indonesia dan ditempatkan dalam posisi yang supreme atau sebagai hukum tertinggi yang berlaku dalam suatu negara (the supreme law of the land). Oleh karena itu, konstitusi tidak saja memiliki makna legal belaka, tetapi juga memiliki makna filosofis dan nilai yang menjadi sumber inspirasi bagi segala kebijakan dalam kehidupan bernegara. (Zoelva, 2016: 304).

Guru idealnya bukan hanya sekedar mengajar tapi juga harus mempunyai jiwa mendidik, karena mengajar beda dengan mendidik. Mengajar hanya memberikan pelajaran sedangkan mendidik diartikan memelihara dan memberikan latihan (ajaran, tuntunan, pimpinan) mengenai akhlak dan kecerdasan pikiran (Departemen Pendidikan Nasional, 2008: 23 \& 326).

Seseorang yang aktif dalam kancah dunia pendidikan harus mempunyai kepribadian sebagai seorang pendidik. Tuntutan akan kepribadian sebagai pendidik kadangkadang dirasakan lebih berat dibandingkan dengan profesi yang lain (Shabir, 2015: 224).

Oleh karena itu seorang Guru harus pula memahami kesadaran terhadap konstitusi (UUD Tahun 1945) dalam segala kegiatan/aktifitas di lingkungan sekolah. Guru ketika melakukan tugas profesionalnya mempunyai tugas dan tanggung jawab yang tidak ringan. Oleh karena itu, Guru harus memiliki dan menguasai kompetensinya dan sekaligus mengetahui hak dan kewajibannya sehingga ia menjadi sosok Guru yang benar-benar profesional (Ibid: 223).

Semua kegiatan di SMP Negeri 77 Jakarta yang berlokasi di Jl. Cempaka Putih Tengah XVII, RT. 2/RW. 8, Kel. Cempaka Putih Timur, Kecamatan Cempaka Putih, Kota Jakarta Pusat-Provinsi Daerah Khusus Ibukota Jakarta adalah sebagai kegiatan yang merupakan bagian dalam konteks bernegara, dimana dalam konteks bernegara rujukan utamanya adalah konstitusi. Oleh karena itu penulis secara keilmuwan tergerak untuk meluaskan pemahaman terhadap UUD Tahun 1945 sebagai konstitusi Indonesia bagi Guru-guru di SMP tersebut.

Berdasarkan apa yang dijabarkan tersebut setidaknya ada dua pokok bahasan yang akan difokuskan dalam program pengabdian ini yaitu: 1.Bagaimanakah meningkatkan pemahaman konstitusi bagi Guru-guru di lingkungan SMP Negeri 77 Jakarta?; dan 2.Pasal-pasal mana sajakah dalam UUD Tahun 1945 yang relevan 
untuk diimple-mentasikan dalam aktifitas di lingkungan SMP Negeri 77 Jakarta.

\section{Pelaksanaan dan Metode}

Pada awal pelaksanaan dilakukan pre test untuk mengetahui sejauh mana pemahaman para Guru secara brainstorming, kemudian dilakukan pembekalan materi dengan cara orasi dan dialog. Setelah pembekalan materi dilakukan, selanjutnya dilakukan post test, untuk mengetahui sejauh mana materi benar-benar terserap dan dipahami oleh para Guru. Secara sampling dari Guru-guru yang hadir dalam kegiatan diminta untuk mempresentasikan wawasan pengetahuannya tentang materi dan berkenaan dengan kasus-kasus aktual yang sedang terjadi dimana kasus tersebut ada kaitannya dengan konstitusi dalam konteks bernegara.

Metode menurut Kamus Besar Bahasa Indonesia diartikan sebagai cara teratur yang digunakan untuk melaksanakan suatu pekerjaan agar tercapai sesuai dengan yang dikehendaki; cara kerja yang bersistem untuk memudahkan pelaksanaan suatu kegiatan guna mencapai tujuan yang ditentukan (Departemen Pendidikan Nasional, 2008: 910).

Metode kegiatan pengabdian yang yang digunakan adalah metode participatory action, yaitu dengan cara orasi, dialog dan pendidikan. Dengan adanya pendekatan yang partisipasif, para Guru yang hadir dapat secara maksimal memahami dan turut mempraktekan secara langsung berdasar-kan apa yang didapat dalam kegiatan orasi dan dialog serta pendidikan.

\section{Hasil dan Pembahasan Persiapan Kegiatan}

Langkah awal yang dilakukan dalam kegiatan pengabdian kepada masyarakat dalam hal meningkatkan pemahaman konstitusi ini adalah penentuan lokasi. Pada akhirnya program pengabdian tersebut dilaksanakan di lokasi SMP Negeri 77 Jakarta yang berlokasi di Jl. Cempaka Putih Tengah XVII, RT. 2/RW. 8, Kel. Cempaka
Putih Timur, Kecamatan Cempaka Putih, Kota Jakarta Pusat-Provinsi Daerah Khusus Ibukota Jakarta.

Setelah penentuan lokasi, maka dilakukan kunjungan ke SMP tersebut dalam rangka permohonan kesediaan dilaksanakan program pengabdian kepada masyarakat yang didanai oleh Universitas YARSI Jakarta. Dalam hal ini permohonannya ditujukan kepada Kepala Sekolah SMP Negeri 77 Jakarta. Kemudian ijin diberikan pada tanggal 7 Februari 2020 agar kegiatan pengabdian kepada masyarakat yang dimaksud dapat terlaksana.

\section{Pelaksanaan Kegiatan}

Pengabdian kepada masyarakat dengan tema "Meningkatkan Pemahaman Konstitusi Bagi Guru-Guru SMP Negeri 77 Jakarta" dilaksanakan pada hari Jumat, 7 Februari 2020, dimulai Pkl 15.00 s.d 17.00 WIB. Dimana kegiatan pengabdian ini diikuti oleh 35 orang guru SMP Negeri 77 Jakarta seperti Gambar 1.

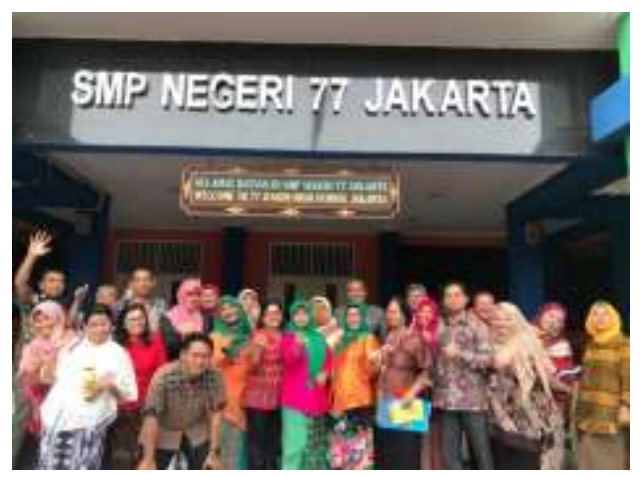

Gambar 1. Tim Dosen dan Guru

\section{Pre-Test}

Sebelum participatory action dilakukan terlebih dahulu dilakukan pre-test yang bertujuan untuk mengetahui sejauh mana pengetahuan responden tentang materi yang akan diberikan. Dimana fungsi pretest tersebut untuk melihat efektifitas kegiatan yang dilakukan (Damayanti, dkk, 2017: 145).

Adapun kuesioner dalam kegiatan pre-test tersebut setidaknya terdapat lima pertanyaan, yaitu: (1) Apakah saudara berminat atau ingin tahu dua jenis hukum dalam bernegara?, (2) Apakah saudara 
berminat atau ingin meluaskan pemahaman terhadap Konstitusi?, (3) Apakah saudara berminat atau ingin mengetahui Konstitusi yang pernah berlaku di Indonesia?, (4) Apakah saudara berminat atau ingin mengetahui fungsi Konstitusi?, dan (5) Apakah saudara berminat atau ingin mengetahui metode perubahan Konstitusi. Hasil dari kuesioner pada tahap pre-test tersebut sebagaimana pada tabel 1 berikut.

Tabel 1. Hasil Pre-Test

\begin{tabular}{cccccc}
\hline Pertanyaan & STI & TI & CI & I & SI \\
\hline 1 & 25 & 3 & 2 & 3 & 2 \\
\hline 2 & 23 & 4 & 3 & 2 & 3 \\
\hline 3 & 13 & 7 & 2 & 3 & 10 \\
\hline 4 & 10 & 7 & 5 & 2 & 11 \\
\hline 5 & 15 & 10 & 4 & 3 & 3 \\
\hline Total & $\mathbf{8 6}$ & $\mathbf{3 1}$ & $\mathbf{1 6}$ & $\mathbf{1 3}$ & $\mathbf{2 9}$
\end{tabular}

Keterangan :

STI = Sangat Tidak Ingin

TI $=$ Tidak Ingin

$\mathrm{CI}=$ Cukup Ingin

I = Ingin

SI = Sangat Ingin

\section{Participatory Action}

Metode pelaksanaan yang dilakukan dalam kegiatan pengabdian ini adalah metode participatory action dengan metode orasi, dialog dan pendidikan. Metode orasi dan dialog digunakan untuk menyampaikan perluasan pemahaman terhadap konstitusi serta melakukan dialog dalam ruang lingkup UUD Tahun 1945 yang merupakan konstitusi Indonesia sebagai hukum tertinggi, yang pada akhirnya meningkatkan kesadaran berkonstitusi dalam segala aktifitas di lingkungan sekolah seperti pada Gambar 2.

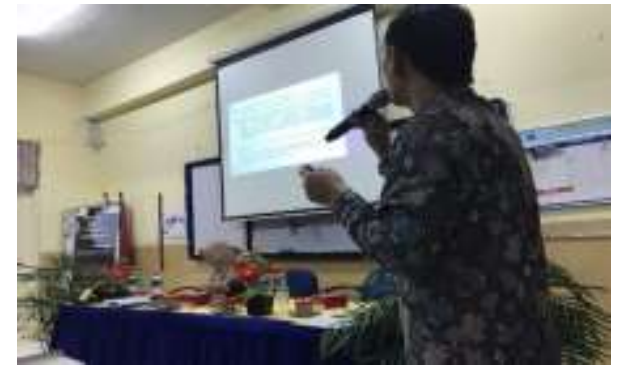

Gambar 2. Pelaksanaan Participatory Action.

Setidaknya terdapat delapan materi yang disampaikan dalam sesi orasi dan dialog. Pertama, Hubungan antara profesi guru dan hukum. Materi ini menjelaskan sebagaimana berdasarkan Pasal 1 angka 1 UU Guru dan Dosen disebutkan: "Guru adalah pendidik profesional dengan tugas utama mendidik, mengajar, membimbing, mengarahkan, melatih, menilai, dan mengevaluasi peserta didik pada pendidikan anak usia dini jalur pendidikan formal, pendidikan dasar, dan pendidikan menengah.”

Selanjutnya dalam Pasal 20 huruf d UU Guru dan Dosen disebutkan bahwa dalam melaksanakan tugas keprofesionalan, Guru berkewajiban: "Menjunjung tinggi peraturan perundang-undangan, hukum, dan kode etik guru, serta nilai-nilai agama dan etika."

Berdasarkan pemahaman dua pasal tersebut dapat dimaknai bahwa guru selain dikatakan sebagai pendidik profesional namun juga berkewajiban menjunjung tinggi peraturan perundang-undangan. Artinya dalam hal tersebut, telah sesuai dengan pengabdian kepada masyarakat yang dilakukan dengan tema: "Meningkatkan Pemahaman Konstitusi Bagi Guru-Guru SMP Negeri 77 Jakarta". Sebagaimana diketahui dalam sistem hukum Indonesia bahwa UUD Tahun 1945 yang juga sebagai konstitusi Indonesia merupakan sumber utama dalam konteks bernegara.

Kedua, Hierarki hukum. Dalam sistem hukum Indonesia hierarki hukumnya dimanifestasikan dalam UU No. 12 Tahun 2011 tentang Pembentukan Peraturan Perundang-Undangan, yaitu sebagai berikut:

1. Undang-Undang Dasar Negara Republik Indonesia Tahun 1945;

2. Ketetapan MPR;

3. Undang-Undang/Peraturan Pemerintah Pengganti Undang-Undang;

4. Peraturan Pemerintah;

5. Peraturan Presiden;

6. Peraturan Daerah.

Ketiga, Dua jenis hukum dalam bernegara. Pada bagian ini menjelaskan sebagaimana pendapat Mac Iver (Ali, 2009: 467), yaitu: 
"Even within the sphere of the state thre are two kinds of law. There is the law a which governs the state and there is the law by means of which the state governs. The former is Constitutional law, the latter we may for the sake of distinction call ordinary law (Dalam alam bernegara, ada dua jenis hukum. Ada hukum yang mengemudikan negara dan ada hukum yang digunakan negara sebagai alat memerintah. Hukum yang mengemudikan negara adalah hukum konstitusi, sedang yang lain untuk kepentingan pembedaan kita sebut hukum biasa)."

Keempat, Unsur utama hukum tata negara adalah konstitusi. Terkait materi ini dihubungkan dengan sebagaimana pendapat John Alder (2002: 4), yaitu: "Konstitusi sebagai unsur utama Hukum Tata Negara, oleh karena itu studi tentang Hukum Tata Negara harus selektif tetapi setidaknya harus mencakup tujuan luas dari politik pengaturan negara yang bersangkutan dan hak-hak utama dari individu yang dilindungi oleh hukum".

Kelima, Fungsi konstitusi. Pemaparan materi ini diberikan sebagaimana pendapat Jimly Asshiddiqie (2010: 29), yaitu: "Konstitusi adalah hukum dasar yang difungsikan sebagai pegangan dalam penyelenggaraan suatu negara. Konstitusi dapat berupa hukum dasar tertulis yang lazim disebut Undang-Undang Dasar, dan dapat pula tidak tertulis".

Keenam, Konstitusi yang pernah berlaku di Indonesia. Ada pepatah mengatakan bahwa salah satu ciri bangsa yang baik adalah: "jangan lupa dengan sejarah". Oleh karena itu ada baiknya pula sebagai bangsa Indonesia mengetahui konstitusi apa saja yang pernah berlaku di Indonesia, berikut urutannya:

1. Undang-Undang Dasar Negara Republik Indonesia (UUD 1945) yang ditetapkan oleh panitia persiapan kemerdekaan Indonesia pada tanggal 18 Agustus 1945. Oleh karena itu UUD Tahun 1945 dikatakan sebagai konstitusi yang pertama berlaku di Indonesia.
2. Konstitusi Republik Indonesia Serikat Tahun 1949 yang merupakan hasil Konferensi Meja Bundar di Den Haag pada tanggal 27 Desember 1949. Oleh karena itu konstitusi yang kedua ini biasa disebut dengan istilah Konstitusi RIS 1949.

3. Undang-Undang Dasar Sementara Tahun 1950 yang ditetapkan pada tanggal 15 Agustus 1950 dengan UU No. 7 Tahun 1950. Oleh karena itu konstitusi yang ketiga ini biasa disebut dengan istilah UUDS 1950.

4. Konstitusi keempat, sama halnya dengan konstitusi pertama (UUD Tahun 1945), dalam hal ini sebagaimana berdasarkan amanat Dekrit Presiden 5 Juli 1959.

5. Sedangkan konstitusi kelima yang masih berlaku sampai saat ini adalah UndangUndang Dasar Negara Republik Indonesia Tahun 1945 (UUD Tahun 1945) sebagaimana diketahui yang telah mengalami amandemen sebanyak empat kali, yaitu dari tahun 1999 sampai tahun 2002.

Ketujuh, Metode perubahan konstitusi. Materi ini diberikan agar mengetahui dengan cara apa saja bisa terjadi perubahan konstitusi. Oleh karena itu patut pula menjabarkan sebagaimana dikatakan oleh K.C. Wheare, metode perubahan konstitusi setidaknya dapat dengan tiga cara, yaitu: (i) formal amendement, (ii) judicial Interpretation dan (iii) constitutional usage and conventions. Yang tentunya pula metode perubahan-perubahan tersebut dalam arti menambah, mengurangi, atau memperbaiki makna terdapat dalam suatu teks UUD (Asshiddiqie, 2009: 219).

Seperti diketahui pula, bahwa ketiga metode perubahan tersebut sudah pula pernah terjadi di Indonesia. Formal amendement, yaitu sebagaimana adanya perubahan UUD Tahun 1945 sebanyak empat kali, yaitu dari tahun 1999 sampai tahun 2002. Judicial Interpretation; sebagaimana adanya Putusan Mahkamah Konstitusi No. 138/PUU-VII/2009, Mahkamah menyatakan berwenang uji konstitusional Peraturan Pemerintah Pengganti Undang-Undang 
(Perppu). Padahal secara tekstual dalam UUD Tahun 1945 tidak disebutkan bahwa Mahkamah Konstitusi berwenang uji konstitusional Perppu. Begitu pula dalam hal constitutional usage and conventions, yaitu dengan adanya kebiasaan setiap tahun adanya pidato kenegaraan yang dilakukan Presiden dalam rangka merayakan Hari Ulang Tahun Kemerdekaan Republik Indonesia.

Kedelapan, Anak berdasarkan perspektif Hak Asasi Manusia dalam UUD Tahun 1945. Salah satu tujuan perubahan UUD 1945 adalah menyempurnakan aturan dasar mengenai jaminan dan perlindungan Hak Asasi Manusia (HAM) agar sesuai dengan perkembangan paham HAM dan peradaban umat manusia yang sekaligus merupakan syarat bagi suatu negara hukum dicita-citakan oleh UUD Tahun 1945. Materi HAM dalam UUD NRI 1945 terdapat di Bab X Hak Asasi Manusia yaitu Pasal 28A sampai 28J. Dari berbagai pasal terkait HAM tersebut, menarik untuk diperhatikan adalah adanya kata "anak" hanya ada satusatunya terdapat dalam 28B ayat (2) UUD Tahun 1945, dimana pasal a quo disebutkan: "Setiap anak berhak atas kelangsungan hidup, tumbuh, dan berkembang serta berhak atas perlindungan dari kekerasan dan diskriminasi".

Sebagaimana diketahui usia rata-rata peserta didik Sekolah Menengah Pertama (SMP) adalah sekitar 12 sampai 16 tahun. Oleh karena usianya sekitar tersebut maka peserta didik SMP masuk dalam kategori anak. Dalam sudut pandang perspektif teori pilihan, anak-anak tidak menikmati sebagian besar hak konstitusional karena mereka tidak mempunyai kapasitas untuk pilihan otonom. Teori ini memberikan pengertian bahwa anak-anak tidak mempunyai hak dewasa karena mereka kurang mandiri membuat keputusan (Dailey, 2011: 2101).

Oleh karena itu pula dengan adanya keberadaan Pasal 28B ayat (2) UUD NRI 1945 para Guru harus pula menyadari bahwa para guru mempunyai tanggung jawab agar hak-hak konstitusional anakanak (peserta didik SMP) sebagaimana dimaksud pasal a quo dapat dimplementasikan dalam segala kegiatan di lingkungan sekolah.

\section{Post-Test Pasca Participatory Action}

Setelah participatory action dilakukan dilanjutkan post-test. Dalam hal ini kuesioner dalam kegiatan post-test sama dengan pertanyaan yang diberikan pada saat pre-test. Adapun hasil dari post-test tersebut sebagaimana tabel 2 berikut.

Tabel 2. Hasil Post-Test

\begin{tabular}{cccccc}
\hline Pertanyaan & STI & TI & CI & I & SI \\
\hline 1 & 0 & 3 & 2 & 3 & 27 \\
\hline 2 & 0 & 4 & 3 & 2 & 26 \\
\hline 3 & 0 & 7 & 2 & 3 & 23 \\
\hline 4 & 0 & 7 & 5 & 2 & 21 \\
\hline 5 & 0 & 10 & 4 & 3 & 18 \\
\hline Total & $\mathbf{0}$ & $\mathbf{2 6}$ & $\mathbf{2 0}$ & $\mathbf{1 5}$ & $\mathbf{1 1 7}$ \\
\hline
\end{tabular}

\section{Simpulan}

\section{Penutup}

Berdasarkan hasil dari perbandingan hasil dari jawaban pada saat pre-test dan post-test secara menyeluruh yang tanpa mengklasifikasikan pertanyaannya ternyata terjadi peningkatan dengan jumlah yang signifikan, dalam hal ini sebagaimana tabel 3 berikut.

Tabel 3 Perbandingan Hasil

Pre-Test dan Post-Test

\begin{tabular}{cccccc}
\hline $\begin{array}{c}\text { Pre/Post } \\
\text { Test }\end{array}$ & STI & TI & CI & I & SI \\
\hline Pre-Test & 86 & 31 & 16 & 13 & 29 \\
\hline Post-Test & 0 & 10 & 20 & 15 & 140 \\
\hline $\begin{array}{c}\text { Total Hasil } \\
\text { Peningkatan }\end{array}$ & $\mathbf{8 6}$ & $\mathbf{2 1}$ & $\mathbf{4}$ & $\mathbf{2}$ & $\mathbf{1 1 9}$ \\
\hline
\end{tabular}

Secara sederhana jika diambil dari yang menjawab Sangat Tidak Ingin (STI) dengan pertanyaan: "Apakah saudara berminat atau ingin tahu dua jenis hukum dalam bernegara" dan Sangat Ingin (SI) dengan pertanyaan: "Apakah saudara berminat atau ingin mengetahui metode perubahan Konstitusi" sebagaimana berdasarkan tabel 3 tersebut terjadi peningkatan total hasilnya, artinya pengabdian masyarakat dengan tema: "Meningkatkan Pema- 
haman Konstitusi Bagi Guru-Guru Di SMP Negeri 77 Jakarta" sangat bermanfaat.

\section{Saran}

Seringkali pula sebagai Dosen melakukan pengabdian masyarakat pada tingkat Sekolah Menengah Pertama (SMP) dan Sekolah Menengah Atas (SMA), terlebih Konstitusi Indonesia (UUD Tahun 1945) telah mengalami perubahan tidak hanya secara formal saja. Oleh karena itu perlu pula menjelaskan pemahaman kenapa hal tersebut bisa terjadi.

\section{Ucapan Terima Kasih}

Diucapkan terima kasih yang sebesar-besarnya kepada Universitas YARSI yang telah mendanai pengabdian masyarakat ini dapat terselenggara. Begitu pula diucapkan terima kasih kepada Kepala Sekolah, Guru-guru dan Staf SMP Negeri 77 Jakarta sehingga pengabdian masyarakat ini dapat terlaksana dengan baik.

\section{Daftar Pustaka}

Alder, John. 2002. General Principles of Constitutional and Administrative Law. Fourth Edition. Palgrave Macmillan. New York.

Ali, Achmad. 2009. Menguak Teori Hukum (Legal Theory) \& Teori Peradilan (Judicialprudence): Termasuk Interpretasi Undang-Undang (Legisprudence) Volume 1 Pemahaman Awal. Ed. 1 Cet. I. Kencana Prenada Media Group. Jakarta.

Asshiddiqie, Jimly. 2010. Konstitusi \& Konstitusionalisme Indonesia. Ed. Kedua. Cet. Pertama. Sinar Grafika. Jakarta.

Asshiddiqie, Jimly. 2009. Pengantar Ilmu Hukum Tata Negara. Ed. 1. PT Rajawali Pers. Jakarta.

Dailey, Anne C. 2011. Children's Constitutional Rights. Minnesota Law Review, (95:2099): 20992179.
Damayanti, dkk. 2017. Metode Pre-Test dan Post-Test Sebagai Salah Satu Alat Ukur Keberhasilan Kegiatan Penyuluhan Kesehatan Tentang Tuberkulosis di Kelurahan Utan Panjang, Jakarta Pusat. Prosiding Seminar Nasional Penelitian dan PKM Kesehatan. Vol. 3 No. 1: 144150.

Departemen Pendidikan Nasional. 2008. Kamus Besar Bahasa Indonesia, edisi keempat. PT. Gramedia PustakaUtama. Jakarta.

M. Shabir U. 2015. Kedudukan Guru Sebagai Pendidik. Auladuna: Vol. 2 No. 2: 221-232.

Undang-Undang Dasar Negara Republik Indonesia Tahun 1945.

Undang-Undang No. 14 Tahun 2005 tentang Guru dan Dosen.

Zoelva, Hamdan. 2016. Mengawal Konstitusionalisme. Cetakan Pertama. Konstitusi Press. Jakarta. 